\title{
BMJ Open Availability and affordability of biologic versus non-biologic anticancer medicines: a cross-sectional study in Punjab, Pakistan
}

Anum Saqib, ${ }^{1}$ Sadia Iftikhar, ${ }^{2}$ Muhammad Rehan Sarwar ${ }^{1,2}$

To cite: Saqib A, Iftikhar S, Sarwar MR. Availability and affordability of biologic versus non-biologic anticancer medicines: a cross-sectional study in Punjab, Pakistan. BMJ Open 2018;8:e019015. doi:10.1136/ bmjopen-2017-019015

- Prepublication history and additional material for this paper are available online. To view these files, please visit the journal online (http://dx.doi. org/10.1136/bmjopen-2017019015).

AS and MRS contributed equally.

Received 4 August 2017 Revised 25 February 2018 Accepted 1 May 2018

Check for updates

${ }^{1}$ Department of Pharmacy, The Islamia University of Bahawalpur, Bahawalpur, Punjab, Pakistan

${ }^{2}$ Department of Pharmacy Practice, Akhtar Saeed College of Pharmaceutical Sciences, Lahore, Pakistan

Correspondence to Dr Muhammad Rehan Sarwar; rehansarwaralvi@gmail.com

\section{ABSTRACT}

Objectives Prime focus of this study was to evaluate the availability and affordability of originator brands (OBs) and lowest price generics (LPGs) of prescribed biologic and non-biologic anticancer medicines.

Design, settings and participants A descriptive, cross-sectional survey was conducted in 22 cancer-care hospitals (18 public hospitals and 4 private hospitals) and 44 private pharmacies in Punjab, Pakistan. Sampling population consisted of 4483 patients with cancer aged $\geq 18$ years. The availability was determined by classifying anticancer medicines in four categories: absent/ unavailability (medicines not present in any surveyed facility), low availability (medicines present in $<50 \%$ of surveyed facilities), fairly high availability (medicines present in $50 \%-74 \%$ of surveyed facilities) and high availability (medicines present in $>75 \%$ of surveyed facilities). Medicines were affordable if overall cost of all the prescribed anticancer medicines were $20 \%$ of the household capacity to pay. Data were analysed by using Statistical Packages for Social Sciences (IBM SPSS Statistics for Windows, V.21.0)

Results A total of 5060 patients with cancer were approached out of which 4483 patients were included in the survey. Overall, 10103 anticancer drugs were prescribed. Among them, 96.3\% were non-biologics and $3.7 \%$ were biologics. Oncologists were reluctant to prescribe biologics due to high prices. $58.1 \%$ of nonbiologics were affordable; whereas, the affordability of biologics was $3.3 \%$. A total of $43.9 \%$ of both biologic and non-biologic OBs were available; whereas, their affordability was $44.2 \%$. On the other hand, the availability of LPGs was $21.3 \%$, and their affordability was $66.1 \%$. For low-income patients, the affordability of non-biologics was $31.6 \%$ and the affordability of biologics was $1.1 \%$.

Conclusions Most of the patients with cancer were prescribed non-biologics due to their low price and better affordability. In contrast to OBs, LPGs of both biologics and non-biologics had less availability but more affordability.

\section{INTRODUCTION}

Cancer is one of the most lethal non-communicable diseases. The advancement in medical and pharmaceutical sciences has resulted in a wide range of therapeutic options for treating this disease that mainly

\section{Strengths and limitations of this study}

To the best of our knowledge, it is the first study that compares the biologic and non-biologic anticancer medicines with respect to the availability of their lowest price generics and originator brands in public and private settings and affordability among patients of different income classes in low/middle-income countries like Pakistan.

- Non-biologics having more than one active ingredient or prescribed in combination with biologics were not evaluated.

- Biologics other than protein kinase inhibitors and monoclonal antibodies were not evaluated in this study since they were not prescribed to the selected patients.

includes non-biologic and biologic anticancer medicines. ${ }^{1}$ According to Food and Drug Administration (FDA), biologics are made up of protein, sugar or nucleic acid or their complex combination or may be living entities (eg, tissues and cells). These are isolated from biological origin and produced by using cutting-edge techniques and biotechnological processes. ${ }^{2}$ The major issue in using non-biologic or chemotherapeutic agents is the non-specific killing of cells. The approval of rituximab by FDA as a first biologic agent for treating cancer led to a new era of anticancer drugs in $1997 .^{3}$ The greater efficacy and decreased toxicity has made biologics superior. In contrast to conventional non-biologics, biologic medicines have proven to improve the survival rates and patient's quality of life. ${ }^{4}$ However, the substantial cost of biologics is a source of huge financial encumbrance for the patients. According to an estimate the average per-month cost of anticancer medicines has increased by more than two folds (ie, from $\$ 4500$ to $>\$ 10000$ in the last decade) ${ }^{56}$ In 2007, the American Society of Clinical Oncology has established 
a task force to identify the factors responsible for high prices of anticancer medicines. ${ }^{7}$

Worldwide, there is a dearth of availability of anticancer drugs at affordable prices. In many regions of the world, the affordability is defined as the costs which do not pose a financial encumbrance on patients. The high prices of biologics and non-biologics among different regions of the world and non-availability of lowest price generics (LPGs) particularly for biologics are the root causes of this economic burden. ${ }^{8}$ Since the patients in low/middle-income countries (LMICs) find it difficult to afford non-biologics, their treatment with new therapeutic agents like biologic is almost impossible. Therefore, the management of cancer is seriously affected by the availability and affordability of anticancer agents. ${ }^{9}$

Some probable reasons which might hinder the accessibility of LPGs may include the reimbursement, budget allocation, manufacturing processes, patent rights, data exclusivity and bioequivalent studies. ${ }^{410-13}$ Also, 'mark-up values' by the hospitals, wholesale dealers, pharmacists and physicians may contribute in making the prices extremely high. ${ }^{1415}$ Moreover, a preapproval is needed for the provision of subsidised medicines. This may cause poor access towards therapeutic agents, and it ultimately leads to a considerable delay in the commencement of treatment. ${ }^{16}$ Consequently, recovery of patients is negatively affected. A study by the Association of Oncology Social Work has reported symptoms of anxiety and depression among patients with cancer due to te economic burden associated with cancer treatment. ${ }^{12}$

The poor availability and affordability of anticancer drugs is a common issue in Pakistan. There are evidences that depict the formulary limitation and resource allocation as the major causes for this drastic issue. The shortage of anticancer drugs and unavailability of formulary for these agents are due to weak healthcare system and poor collaboration of healthcare professionals. The improper allocation of budget also makes the anticancer drugs especially biologics unaffordable for both government and local masses. ${ }^{17} 18$ If the anticancer medicines are unavailable or unaffordable for the patients then it would not only aggravate their underlying disease but it would also lead to the inequities between the patients who can get them versus those who fail to get access to those medicines.

The WHO and the Health Action International (HAI) have given a standard methodology for evaluating affordability ${ }^{19}$ and numerous studies focusing on the gravity of underlying problem have been conducted in multiple countries. However, affordability in the current study has not been evaluated by this method because anticancer medicines are quite expensive, and the WHO and HAI methodology does not fit true for anticancer medicines. It is crucial to determine the method in the context of the country and the medicine class. ${ }^{19}$ To date, no study has been conducted to find out the affordability of anticancer medicines, and it demands formulating the appropriate method/formula for determining the affordability of anticancer medicines. The aim of the current study is to assess the availability of biologic and non-biologic anticancer medicines in public and private sectors, and their affordability by high-income, middle-income and low-income class patients.

\section{METHODS}

\section{Study design and settings}

A descriptive, cross-sectional study design was employed. There are total 23 (18 public and 4 private sector tertiary care) hospitals in Punjab province of Pakistan which provide services to patients with cancer. Out of these 23 hospitals, 7 are specialised cancer-care hospitals. Except for one hospital (which provides services solely to the paediatrics), all the hospitals providing services to patients with cancer in Punjab province of Pakistan were included in the current study. Survey was carried out in 22 cancer-care hospitals and 44 private pharmacies in Punjab province of Pakistan. Data were collected from patients with cancer attending the study settings and evaluated according to the objectives of the study.

\section{Study population and sample size}

The population under study was patients with cancer aged $\geq 18$ years, who visited the selected cancer-care hospitals for routine examinations. A total of 200 patients with cancer were randomly approached from each hospital, thus leading to a sample size of 4400 . However, with the contingency of $15 \%$ for non-response and inappropriate responses, the sample size was 5060 .

A total of 5060 patients with cancer were approached over a 6-month period (1 January 2017 to 30 June 2017), out of which 4613 patients responded to the survey (response rate $=91.2 \%$ ). The remaining patients were not willing to participate in the study due to several reasons such as illiteracy, superstitions, shortage of time due to household responsibilities and previous worse experiences. Out of 4613 patients with cancer 130 had missing information, therefore they were excluded from the study. Thus, 4483 patients with cancer were finally included in the survey.

\section{Data collection and outcome variables}

A data collection form was designed for this study which consisted of three main parts: (1) sociodemographic characteristics, (2) diagnosis and (3) recommended medicines. The reliability and internal consistency of the survey tool were assessed by conducting a pilot study. Piloting was undertaken using data from 100 patients. The data were collected only once from the study settings. There was no repetition of interviews or visits.

\section{Measurements}

Sociodemographic characteristics

The following categorical variables were recorded: gender (male/female), age (18-39, 40-64, $\geq 65$ years), civil status (single, married, divorced, widowed), education level (primary, secondary, tertiary), annual income 
(low, middle, upper class), residence (rural, urban) and employment status (employed, unemployed). The retired participants (taking pension) or those running a business were classified as employed and housewives were considered as unemployed. The data were obtained through face-to-face questioning of patients. The data on annual income were determined from Household Integrated Economic Survey 2016 conducted by Pakistan Bureau of Statistics. ${ }^{20}$ Detailed investigation about household possessions, average monthly household income, average monthly household consumption and per-capita monthly consumption expenditure was carried out for evaluating their socioeconomic status. As in Pakistani cultural context women did not know the income of the family, all the data were verified from the head of their family. The data regarding employment status and income level of the participants were validated by using online tax payer verification system of Federal Board of Revenue. ${ }^{21}$

\section{Diagnosis and prescribing pattern}

The type of cancer and all the medicines prescribed to patients were noted on a predesigned pro-forma sheet. The most commonly prescribed anticancer medicines were categorised according to the prescribing trend; low (prescribed to $<5 \%$ of the selected patients), medium (prescribed to $\geq 5 \%$ of the selected patients but $<10 \%$ ) and high (prescribed to $>10 \%$ of the selected patients).

\section{Availability of anticancer medicines and their per month cost}

Fifty anticancer medicines were recorded in the survey. Biologics other than protein kinase inhibitors and monoclonal antibodies were not evaluated in the study since they were not prescribed to the selected patients. The anticancer medicines were selected on the basis of: (a) pilot study in which local needs and cancer burden were assessed, (b) literature review and (c) the opinions of various experts. The medicines were considered available if they were present at the study setting during the survey. The availability of anticancer medicines was evaluated in public hospitals, private hospitals and private pharmacies. For the assessment of prices associated with these medicines, Pharmaguide 2016 was consulted. ${ }^{22}$ Data collection was carried out by trained pharmacy students under the supervision of the survey manager and the principal investigator. The principal investigator checked the collected and completed pro formas on a weekly basis. A follow-up visit to the respective setting was conducted in case any information was missing. Before the initiation of the process of data collection, medical superintendents/ directors were contacted by the principal investigator. In this way, a good cooperation was established between the team of investigators and the staff members of the selected settings. To avoid reporting biases (eg, up coding, less availability of medicine to gain attention for budget increase, etc), the drugs were said to be available if they were present in the settings, and the patients could avail them on prescription. Also, the formulary list and purchase records were assessed for data validation. For each medicine, data were collected on the basis of per-unit price and availability of originator brands (OBs) and LPGs. On the basis of standard guidelines and the recommended treatment, per-unit price of anticancer agents were transformed into per-month cost.

Furthermore, the following criteria were used to describe the availability of medicines ${ }^{23}$ :

Absent/unavailability: $0 \%$ of facilities-these medicines were not found in any facility surveyed.

Low: $<50 \%$ of facilities-these medicines were hard to find.

Fairly high: $50 \%-74 \%$ of facilities-these medicines were available in many facilities.

High: $>75 \%$ of facilities—good availability.

\section{Affordability of anticancer medicines}

The WHO and HAI methodology states that the income of how many days is required to purchase the medicines for 30 days needs to be determined for evaluating affordability. Generally, if the total cost of therapy for 1 month is equal to or less than the wage of 1 day then it is said to be affordable.

The method used in current study for assessing affordability is not validated from the previously published literature. But the expert opinion of researchers and policy-makers was taken into consideration while designing this methodology. The concept of cut-off value by Khatib et $a t^{24}$ is defined as if the combined cost of therapy is $<20 \%$ of household capacity-to-pay then it can be considered as affordable'. In this study, this concept was modified in such a way that the medicines were affordable if overall cost of all the prescribed anticancer medicines were $20 \%$ of the household capacity to pay. The affordability was measured for each prescribed medicine by low-income, middle-income and high-income class of patients through this formula:

$$
\text { Affordability }=\frac{\% * \text { of household capacity to pay }}{\text { Per month cost of the medicine }} \times 100
$$

*If one medicine was prescribed then it was said to be affordable if it covers $20 \%$ of the household capacity to pay, if two medicines were prescribed then they were said to be affordable if each of them covered $10 \%$ of the household capacity to pay, if three medicines were prescribed then they were said to be affordable if each of them covered $6.7 \%$ of the household capacity to pay and if four medicines were prescribed then they were said to be affordable if each of them covered $5 \%$ of the household capacity to pay.

\section{Statistical analysis}

Statistical Package for Social Sciences (IBM, SPSS Statistics for Windows, V.21.0) was used for data analysis. Descriptive statistics such as frequencies, percentages and mean were used to present the data. 


\section{Patient and public involvement}

The poor availability and affordability of anticancer medicines is a common issue in Pakistan, and the research question was in line with the priorities and preferences of patients with cancer. The purpose of the study was explained to all the patients prior to the study being conducted. They were informed that it was a descriptive, cross-sectional study in which there would be neither any intervention nor follow-up, and their confidentiality would not be breached. Data were collected by recruiting patients with cancer in the study and evaluating them according to the objectives of the study. The results would be disseminated to study participants by contacting them at their respective email addresses.

\section{RESULTS}

A total of 5060 patients with cancer were approached, out of which 4483 patients were included in the survey. Just over half $(55.4 \%, \mathrm{n}=2485)$ of the participants were male, and $39.3 \%(\mathrm{n}=1768)$ were aged $18-39$ years; $67.5 \%$ $(\mathrm{n}=3029)$ were married, $67.4 \%(\mathrm{n}=3023)$ had secondary education level and $41.8 \%(\mathrm{n}=1874)$ belonged to the upper class; $68.7 \%(\mathrm{n}=3080)$ respondents were employed and three-quarters $(73.7 \%, \mathrm{n}=3302)$ were urban residents (table 1).

The most common cancers diagnosed among participants were non-Hodgkin's lymphoma $(12.2 \%, \mathrm{n}=545)$, breast cancer $(8.5 \%, \mathrm{n}=380)$ and leukaemia (7.6\%, $\mathrm{n}=339$ ) (online supplementary file).

A total of 10103 anticancer medicines were prescribed to 4483 patients. Among them, 96.3\% ( $\mathrm{n}=9729)$ were non-biologics. Other antineoplastic agents (31\%, $\mathrm{n}=3007)$ and antimetabolites $(21.5 \%, \mathrm{n}=2089)$ were the most frequently prescribed groups of non-biologic anticancer medicines. Overall, only $3.7 \% \quad(n=374)$ of the patients were prescribed biologics. Among them, $94.3 \%$ $(\mathrm{n}=353)$ were prescribed protein kinase inhibitors while $5.6 \% \quad(n=21)$ were prescribed monoclonal antibodies. The detailed description about the prescribed anticancer medicines is given in table 2 .

\section{Availability of OBs and LPGs}

Overall, OBs $(43.9 \%)$ were readily available in all the selected settings compared with LPGs $(21.3 \%)$. The high availability of all the anticancer medicines was found in private sector (OBs=62.5\%, LPGs $=15.6 \%)$ compared with public sector $(\mathrm{OBs}=25.1 \%, \mathrm{LPGs}=8.8 \%)$ (table 3 ).

\section{Availability of non-biologics and biologics}

Non-biologics $\quad(\mathrm{OBs}=52.8 \%$, LPGs $=24.3 \%)$ were more readily available compared with biologic anticancer medicines $(\mathrm{OBs}=12.3 \%$, LPGs $=0.0 \%)$. The availability of both non-biologic and biologic agents was found to be more in private sector compared with public sector (table 3).

\begin{tabular}{|c|c|c|c|}
\hline & $\begin{array}{l}\text { Male } \\
(\mathrm{n}=2485)\end{array}$ & $\begin{array}{l}\begin{array}{l}\text { Female } \\
(n=1998)\end{array} \\
\end{array}$ & $\begin{array}{l}\text { Total } \\
(\mathrm{n}=4483)\end{array}$ \\
\hline Variables & n (\%) & n (\%) & n (\%) \\
\hline \multicolumn{4}{|l|}{ Age (years) } \\
\hline $18-39$ & 984 (39.6) & 784 (39.2) & $1768(39.4)$ \\
\hline $40-64$ & 794 (31.9) & $880(44.0)$ & $1674(37.3$ \\
\hline$\geq 65$ & 707 (28.5) & $334(16.7)$ & $1041(23.2$ \\
\hline \multicolumn{4}{|l|}{ Civil status } \\
\hline Single & $108(4.4)$ & $60(3.0)$ & $168(3.8)$ \\
\hline Married & $1747(70.3)$ & $1282(64.2)$ & $3029(67.6$ \\
\hline Widowed & $370(14.9)$ & $514(25.7)$ & $884(19.7)$ \\
\hline Divorced & $260(10.5)$ & $142(7.1)$ & $402(8.9)$ \\
\hline \multicolumn{4}{|l|}{ Education level } \\
\hline Primary ( $\leq 10$ years) & $503(20.2)$ & $0(0.0)$ & $503(11.2$ \\
\hline $\begin{array}{l}\text { Secondary }(11-13 \\
\text { years) }\end{array}$ & $1414(56.9)$ & $1609(80.5)$ & $3023(67.4$ \\
\hline Tertiary ( $\geq 14$ years) & $568(22.9)$ & $389(19.5)$ & $957(21.4$ \\
\hline \multicolumn{4}{|l|}{ Annual income (PKR) } \\
\hline $\begin{array}{l}\text { Low class (0- } \\
299 \text { 999) }\end{array}$ & $662(26.6)$ & $481(24.1)$ & $1143(25.5$ \\
\hline $\begin{array}{l}\text { Middle class } \\
\text { (300 000-999 999) }\end{array}$ & 842 (33.9) & $624(31.2)$ & $1466(32.7$ \\
\hline $\begin{array}{l}\text { Upper class } \\
(\geq 1000000)\end{array}$ & $981(39.5)$ & $893(44.7)$ & $1874(41.8$ \\
\hline \multicolumn{4}{|l|}{ Employment status } \\
\hline Employed & $2187(88.0)$ & 619 (30.9) & $3080(68.7)$ \\
\hline Unemployed & 298 (11.9) & $1379(69.9)$ & $1677(37.4$ \\
\hline \multicolumn{4}{|l|}{ Residence } \\
\hline Rural & 855 (34.4) & $326(16.3)$ & $1181(26.3$ \\
\hline Urban & $1630(65.6)$ & $1672(83.7)$ & $3302(73.7$ \\
\hline \multicolumn{4}{|l|}{ Number of medicines } \\
\hline 1 & 79 (3.2) & 164 (8.2) & $243(5.4)$ \\
\hline 2 & $1781(71.7)$ & $1213(60.7)$ & $2994(66.8$ \\
\hline 3 & 571 (22.9) & $541(27.1)$ & $1112(24.8$ \\
\hline 4 & $54(2.2)$ & $80(4.0)$ & $134(2.9)$ \\
\hline
\end{tabular}

PKR, Pakistani rupee.

\section{Affordability of OBs and LPGs}

OBs $(44.2 \%)$ of all the anticancer medicines were found to be less affordable than LPGs $(66.1 \%)$; however, their affordability varied among different income classes. OBs were more affordable (59.2\%) for high-income class patients, less $(40.4 \%)$ for middle-income patients and least $(24.1 \%)$ for low-income patients (table 4 ).

\section{Affordability of biologics and non-biologics}

Irrespective of the OBs and LPGs, non-biologics (58.1\%) were more affordable than biologics $(3.3 \%)$. Also, non-biologics $(31.6 \%)$ were more affordable for low-income patients than biologics (1.1\%) (table 4). 


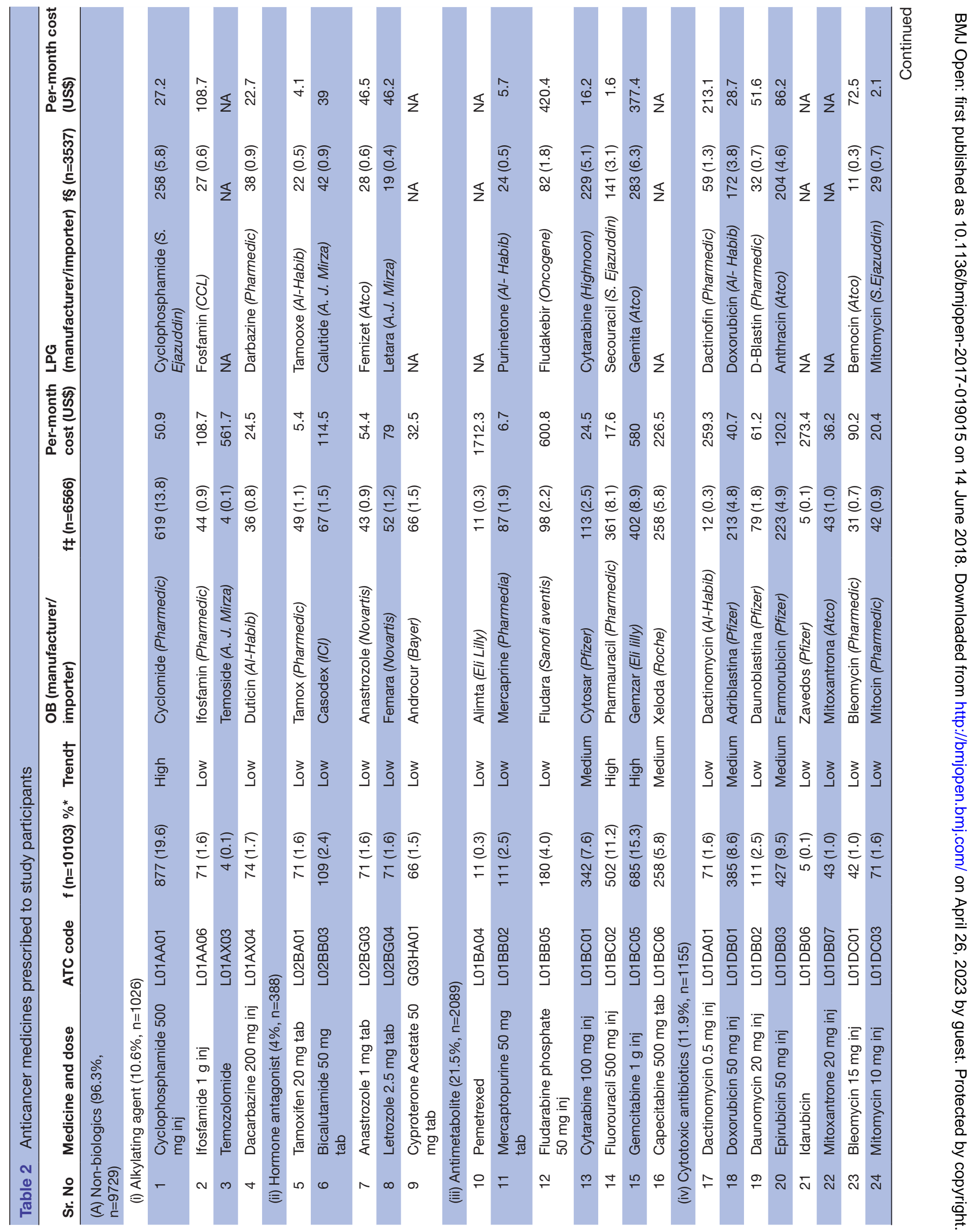




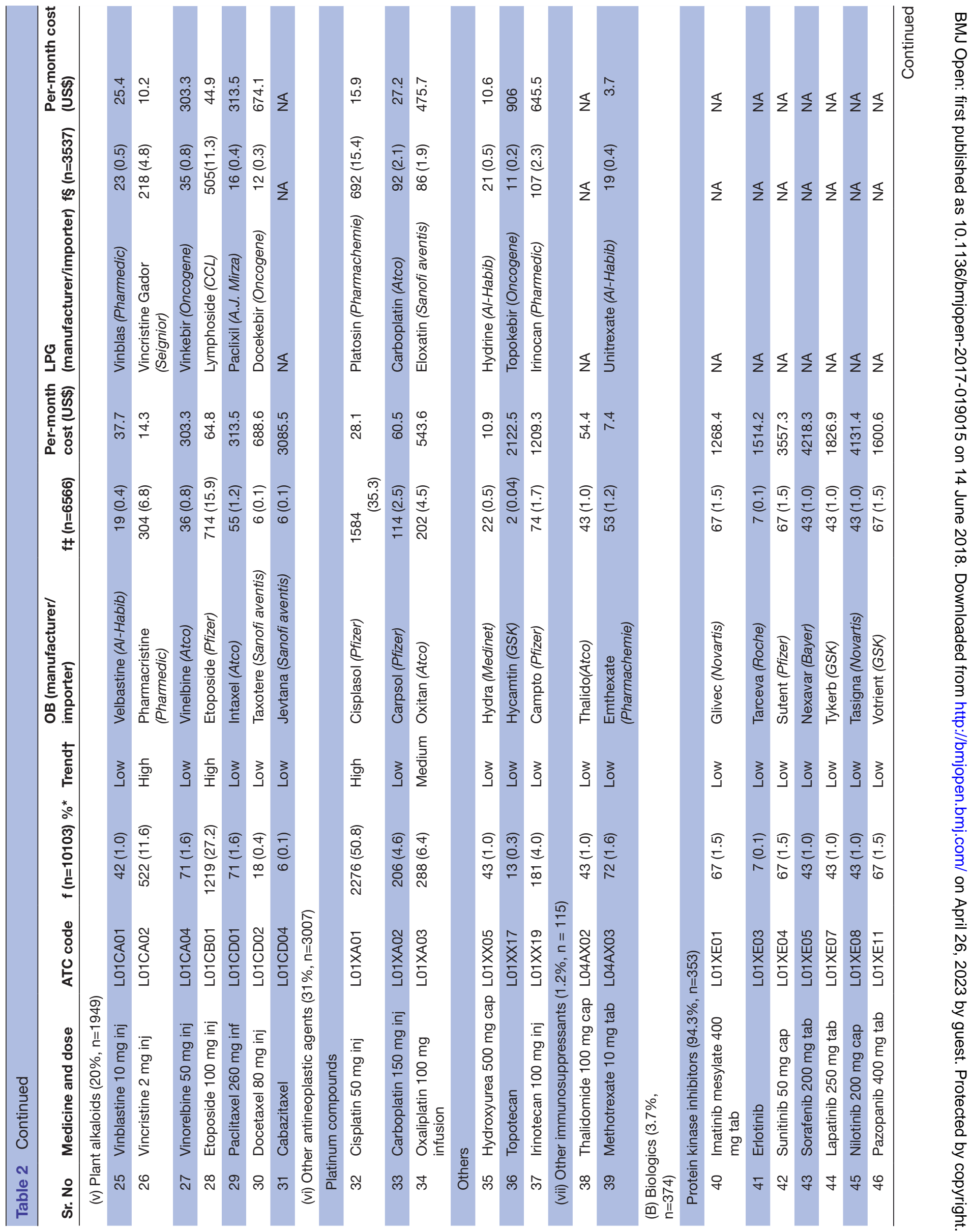


The high prices of OBs and unavailability of LPGs for non-biologics in general and biologic drugs in particular are the global issues in the treatment of cancer. The present study aimed to highlight this ongoing scenario of cancer therapy.

\section{Availability of $\mathrm{OB}$ and LPGs}

The accessibility of bioequivalent LPGs is crucial for increasing survival rates of patients with cancer. These agents must be made available in all public and private healthcare settings, but unfortunately they are unavailable in many LMICs. ${ }^{25}$ Similarly, the findings of the current study showed that the overall availability of OBs (43.9\%) was comparatively higher than the LPGs $(21.3 \%)$ in both sectors. Most of the OBs are patent protected, and the products of the multinational pharmaceutical companies (MPCs). These MPCs spend a huge amount of money on several promotional techniques in order to compete with the local pharmaceutical companies (LPCs) (eg, conducting conferences, continuing medical education for prescribers, awareness campaigns for the patients and providing the opportunities to the physicians of attending foreign conferences), ${ }^{26}$ but financial constraints forbid the LPCs for adopting those strategies. In this way, MPCs successfully promote their products and prescribers are compelled to prescribe these medicines. Hence, the lowest profit margin and collaborative working of LPCs and MPCs are needed for making anticancer drugs available and affordable to the financially constrained patients.

In LMICs, the availability of medicines in the healthcare settings is considerably influenced by the cost. ${ }^{27}$ This study revealed that the availability of these anticancer medicines was high in the private sector $(62.5 \%$ for OBs and $15.6 \%$ for LPGs) compared with the government healthcare settings (25.1\% for OBs and $8.8 \%$ for LPGs). In Pakistan, the provision of health facilities in private sectors is far better than the government sectors. Due to financial crises, the government of Pakistan is unable to maintain good infrastructure of the public healthcare settings. ${ }^{28}$ The government hospitals often face the issue of unavailability or shortage of medicines. This is because the government procures medicines once/twice in a year mainly through the bidding system. On the other hand, private sector is not regulated by the government bodies and prime focus of the private sector is to capture the patient's attention. ${ }^{29}$ Moreover, only the patients with a strong economic background choose private sectors for the diagnosis and treatment of their illness. ${ }^{30}$ Therefore, best quality of health facilities are provided to the patients in private healthcare settings. Similarly, a country-level survey conducted by the WHO in 2001 revealed that the availability of anticancer medicines was very low (43\%) in the South-East Asia, compared with its availability in European region $(91 \%) .{ }^{31}$ The unavailability of medicines in the public sector leads to untoward outcomes for the patients and disease progression. The unavailability or shortage of anticancer medicines in the USA compels 
Table 3 Availability of anticancer medicines in public and private sectors in Punjab, Pakistan

\begin{tabular}{|c|c|c|c|c|c|c|c|c|c|}
\hline \multirow[b]{2}{*}{ Sr. No } & \multirow[b]{2}{*}{ Medicine and dose } & \multicolumn{2}{|c|}{ Public hospitals $(n=18)$} & \multicolumn{2}{|c|}{$\begin{array}{l}\text { Private hospitals } \\
(n=4)\end{array}$} & \multicolumn{2}{|c|}{$\begin{array}{l}\text { Private pharmacies } \\
(n=44)\end{array}$} & \multicolumn{2}{|c|}{ All $(n=66)$} \\
\hline & & OB & LPG & OB & LPG & OB & LPG & OB & LPG \\
\hline \multicolumn{10}{|c|}{ (A) Non-biologics } \\
\hline \multicolumn{10}{|c|}{ (i) Alkylating agent } \\
\hline 1 & $\begin{array}{l}\text { Cyclophosphamide } \\
500 \text { mg inj }\end{array}$ & 15 (83.3) & $3(16.7)$ & $4(100)$ & $0(0.0)$ & 41 (93.2) & $9(20.5)$ & $60(91.0)$ & $12(18.2)$ \\
\hline 2 & Ifosfamide $1 \mathrm{~g}$ inj & $5(27.8)$ & $2(11.1)$ & $2(50.0)$ & $0(0.0)$ & $19(42.3)$ & $21(47.7)$ & $26(39.4)$ & $21(31.8)$ \\
\hline 3 & Temozolomide & $0(0.0)$ & $0(0.0)$ & $1(25.0)$ & $0(0.0)$ & $9(20.5)$ & $0(0.0)$ & 10 (15.2) & $0(0.0)$ \\
\hline 4 & $\begin{array}{l}\text { Dacarbazine } 200 \\
\text { mg inj }\end{array}$ & $4(22.2)$ & $1(5.6)$ & $2(50.0)$ & $1(25.0)$ & $27(61.4)$ & $13(29.5)$ & $33(50.0)$ & $15(22.7)$ \\
\hline Total & percentage & 33.3 & 8.3 & 56.3 & 6.3 & 54.6 & 24.4 & 48.9 & 18.2 \\
\hline \multicolumn{10}{|c|}{ (ii) Hormone antagonist } \\
\hline 5 & $\begin{array}{l}\text { Tamoxifen } 20 \mathrm{mg} \\
\text { tab }\end{array}$ & 15 (83.3) & $2(11.1)$ & $4(100)$ & $2(50.0)$ & $44(100)$ & $16(36.4)$ & $63(95.5)$ & $20(30.3)$ \\
\hline 6 & $\begin{array}{l}\text { Bicalutamide } 50 \mathrm{mg} \\
\text { tab }\end{array}$ & $0(0.0)$ & $0(0.0)$ & $1(25.0)$ & $0(0.0)$ & $3(6.8)$ & $1(2.3)$ & $4(6.1)$ & $1(1.5)$ \\
\hline 7 & $\begin{array}{l}\text { Anastrozole } 1 \mathrm{mg} \\
\text { tab }\end{array}$ & $0(0.0)$ & $0(0.0)$ & $1(25.0)$ & $0(0.0)$ & $4(9.1)$ & $2(4.5)$ & $5(7.6)$ & $2(3.0)$ \\
\hline 8 & Letrozole $2.5 \mathrm{mg}$ tab & $0(0.0)$ & $0(0.0)$ & $2(50.0)$ & $0(0.0)$ & $16(36.4)$ & $8(18.2)$ & 18 (27.2) & $8(12.1)$ \\
\hline 9 & $\begin{array}{l}\text { Cyproterone acetate } \\
50 \mathrm{mg} \text { tab }\end{array}$ & $7(38.9)$ & NA & $4(100)$ & NA & 39 (88.6) & NA & $50(76.0)$ & NA \\
\hline Total & percentage & 24.4 & 2.8 & 60.0 & 12.5 & 48.2 & 15.3 & 42.4 & 11.7 \\
\hline \multicolumn{10}{|c|}{ (iii) Antimetabolite } \\
\hline 10 & Pemetrexed & $0(0.0)$ & $0(0.0)$ & $2(50.0)$ & $0(0.0)$ & $9(20.5)$ & $0(0.0)$ & $11(16.7)$ & 0 \\
\hline 11 & $\begin{array}{l}\text { Mercaptopurine } 50 \\
\text { mg tab }\end{array}$ & $13(72.2)$ & $3(16.7)$ & $4(100)$ & $0(0.0)$ & 41 (93.2) & $11(25.0)$ & 58 (88.0) & $14(21.2)$ \\
\hline 12 & $\begin{array}{l}\text { Fludarabine } \\
\text { phosphate } 50 \mathrm{mg} \text { inj }\end{array}$ & $0(0.0)$ & $0(0.0)$ & $4(100)$ & $1(25.0)$ & $11(25.0)$ & 4 (9.9) & $15(23.0)$ & $5(7.6)$ \\
\hline 13 & $\begin{array}{l}\text { Cytarabine } 100 \text { mg } \\
\text { inj }\end{array}$ & $3(16.7)$ & $0(0.0)$ & $3(75.0)$ & $1(25.0)$ & 34 (77.3) & $7(15.9)$ & 40 (61.0) & $8(12.1)$ \\
\hline 14 & $\begin{array}{l}\text { Fluorouracil } 500 \\
\text { mg inj }\end{array}$ & $16(88.9)$ & $0(0.0)$ & $4(100)$ & $2(50.0)$ & $44(100)$ & $19(43.2)$ & 64 (97.0) & $21(31.8)$ \\
\hline 15 & Gemcitabine $1 \mathrm{~g}$ inj & $5(27.8)$ & $11(61.1)$ & $4(100)$ & $2(50.0)$ & $31(70.5)$ & 41 (93.2) & $40(61.0)$ & $54(81.8)$ \\
\hline 16 & $\begin{array}{l}\text { Capecitabine } 500 \\
\text { mg tab }\end{array}$ & $4(22.2)$ & NA & $4(100)$ & NA & $21(47.7)$ & NA & $29(44.0)$ & NA \\
\hline Total & centage & 32.5 & 12.9 & 89.3 & 25.0 & 62.0 & 31.1 & 55.6 & 25.8 \\
\hline
\end{tabular}

(iv) Cytotoxic antibiotics

17 Dactinomycin $0.5 \quad 8(44.4) \quad 2(11.1) \quad 3(75.0) \quad 1(25.0) \quad 42(95.5) \quad 31(70.5) \quad 53(80.3) \quad 34(51.5)$ mg inj

18 Doxorubicin $50 \mathrm{mg} \quad 14(77.8) \quad 4(22.2) \quad 4(100) \quad 2(50.0) \quad 44(100) \quad 31(70.5) \quad 62(94.0) \quad 37(56.1)$ inj

\begin{tabular}{rlllllllll}
19 & $\begin{array}{l}\text { Daunomycin } 20 \mathrm{mg} \\
\text { inj }\end{array}$ & $2(11.1)$ & $0(0.0)$ & $1(25.0)$ & $1(25.0)$ & $16(36.4)$ & $11(25.0)$ & $19(29.0)$ & $12(18.2)$ \\
\hline 20 & Epirubicin $50 \mathrm{mg}$ inj & $2(11.1)$ & $3(16.7)$ & $4(100)$ & $1(25.0)$ & $14(31.8)$ & $9(20.5)$ & $20(30.3)$ & $13(19.7)$ \\
21 & $\begin{array}{l}\text { Idarubicin } \\
22\end{array}$ & $0(0.0)$ & $0(0.0)$ & $2(50.0)$ & $0(0.0)$ & $7(15.9)$ & $0(0.0)$ & $9(13.6)$ & 0 \\
& $\begin{array}{l}\text { Mitoxantrone 20 } \\
\text { mg inj }\end{array}$ & $0(0.0)$ & NA & $3(75.0)$ & NA & $18(40.9)$ & NA & $21(32.0)$ & NA \\
23 & $\begin{array}{l}\text { Bleomycin 15 mg inj } \\
\text { 10(55.6) }\end{array}$ & $8(44.4)$ & $4(100)$ & $2(50.0)$ & $41(93.2)$ & $27(61.4)$ & $55(83.3)$ & $37(56.1)$ \\
\hline 24 & Mitomycin 10 mg inj & $2(11.1)$ & $0(0.0)$ & $2(50.0)$ & $1(25.0)$ & $31(70.5)$ & $12(27.3)$ & $35(53.0)$ & $13(19.7)$ \\
\hline
\end{tabular}


Table 3 Continued

Public hospitals $(n=18) \quad(n=4)$

Private hospitals Private pharmacies

\begin{tabular}{|c|c|c|c|c|c|c|c|c|}
\hline \multirow[b]{2}{*}{ Medicine and dose } & \multicolumn{2}{|c|}{ Public hospitals $(n=18)$} & \multicolumn{2}{|c|}{$(n=4)$} & \multicolumn{2}{|c|}{$(n=44)$} & \multicolumn{2}{|c|}{ All $(n=66)$} \\
\hline & OB & LPG & OB & LPG & OB & LPG & OB & LPG \\
\hline Total percentage & 26.4 & 13.5 & 71.9 & 28.6 & 60.5 & 39.3 & 51.9 & 31.6 \\
\hline
\end{tabular}

(v) Plant alkaloids

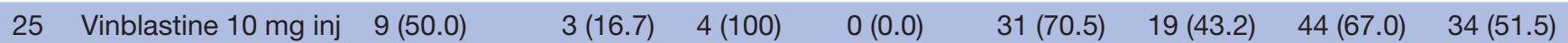

26 Vincristine $2 \mathrm{mg}$ inj $\quad 11(61.1) \quad 2(11.1) \quad 3(75.0) \quad 0(0.0) \quad 33(75.0) \quad 23(52.3) \quad 47(71.2) \quad 25(37.9)$

27 Vinorelbine $50 \mathrm{mg} \quad 0(0.0) \quad 0(0.0) \quad 2(50.0) \quad 2(50.0) \quad 21(47.7) \quad 11(25.0) \quad 23(35.0) \quad 13(19.7)$ inj

28 Etoposide $100 \mathrm{mg} \quad 15(83.3) \quad 0(0.0) \quad 4(100) \quad 0(0.0) \quad 44(100) \quad 13(29.5) \quad 63(95.4) \quad 13(19.7)$ inj

29 Paclitaxel $260 \mathrm{mg} \quad 11(61.1) \quad 4(22.2) \quad 3(75.0) \quad 1(25.0) \quad 44(100) \quad 23(52.3) \quad 58(88.0) \quad 28(42.4)$ inf

30 Docetaxel $80 \mathrm{mg}$ inj $7(38.9) \quad 0(0.0) \quad 3(75.0) \quad 0(0.0) \quad 33(75.0) \quad 7(15.9) \quad 43(65.1) \quad 7(10.6)$

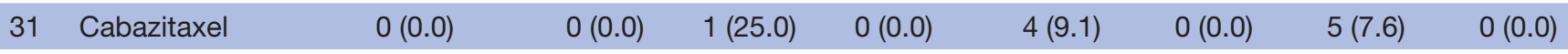

$\begin{array}{lllllllll}\text { Total percentage } & 42.1 & 7.1 & 71.4 & 10.7 & 68.2 & 31.2 & 61.3 & 25.9\end{array}$

(vi) Other antineoplastic agents

Platinum compounds

\begin{tabular}{|c|c|c|c|c|c|c|c|c|c|}
\hline 32 & Cisplatin 50 mg inj & $8(44.4)$ & $9(50.0)$ & $3(75.0)$ & $0(0.0)$ & $43(97.7)$ & $11(25.0)$ & 54 (82.0) & $20(30.3)$ \\
\hline 33 & $\begin{array}{l}\text { Carboplatin } 150 \\
\text { mg inj }\end{array}$ & $13(72.2)$ & $5(27.8)$ & $4(100)$ & $1(25.0)$ & $33(75.0)$ & $29(65.9)$ & $50(76.0)$ & $35(53.0)$ \\
\hline 34 & $\begin{array}{l}\text { Oxalplatin } 100 \mathrm{mg} \\
\text { inf }\end{array}$ & $1(5.6)$ & $0(0.0)$ & $2(50.0)$ & $2(50.0)$ & $21(47.7)$ & $11(25.0)$ & $24(36.4)$ & $13(19.7)$ \\
\hline \multicolumn{2}{|c|}{ Total percentage } & 40.7 & 25.9 & 75.0 & 25.0 & 73.5 & 38.6 & 64.7 & 34.3 \\
\hline \multicolumn{10}{|c|}{ Others } \\
\hline 35 & $\begin{array}{l}\text { Hydroxyurea } 500 \\
\text { mg cap }\end{array}$ & $7(38.9)$ & $0(0.0)$ & $3(75.0)$ & $0(0.0)$ & $23(52.3)$ & $11(25.0)$ & $33(50.0)$ & $11(16.7)$ \\
\hline 36 & Topotecan & $0(0.0)$ & $0(0.0)$ & $1(25.0)$ & $1(25.0)$ & $4(9.1)$ & $5(11.4)$ & $5(7.6)$ & $5(7.6)$ \\
\hline 37 & $\begin{array}{l}\text { Irinotecan } 100 \mathrm{mg} \\
\text { inj }\end{array}$ & $0(0.0)$ & $0(0.0)$ & $2(50.0)$ & $0(0.0)$ & $11(25.0)$ & $10(22.7)$ & $13(20.0)$ & $10(15.2)$ \\
\hline \multicolumn{2}{|c|}{ Total percentage } & 12.9 & 0.0 & 50.0 & 8.3 & 28.8 & 19.7 & 25.8 & 13.1 \\
\hline
\end{tabular}

(vii) Other immunosuppressants

\begin{tabular}{|c|c|c|c|c|c|c|c|c|c|}
\hline 38 & $\begin{array}{l}\text { Thalidomide } 100 \mathrm{mg} \\
\text { cap }\end{array}$ & $4(22.2)$ & NA & $4(100)$ & NA & $25(56.8)$ & NA & $33(50.0)$ & NA \\
\hline 39 & $\begin{array}{l}\text { Methotrexate } 10 \mathrm{mg} \\
\text { tab }\end{array}$ & 15 (83.3) & $1(5.6)$ & $4(100)$ & $1(25.0)$ & 44 (100) & $19(43.2)$ & $63(95.4)$ & 21 (31.8) \\
\hline
\end{tabular}

$\begin{array}{lrrrrrrrr}\text { Total percentage } & 52.8 & 2.8 & 100 & 12.5 & 78.4 & 21.6 & 72.7 & 15.9 \\ \text { Total percentage (non- } & 32.2 & 10.0 & 71.8 & 17.8 & 59.4 & 30.2 & 52.8 & 24.3\end{array}$

biologics)

(B) Biologics

Protein kinase inhibitors

\begin{tabular}{|c|c|c|c|c|c|c|c|c|c|}
\hline 40 & $\begin{array}{l}\text { Imatinib mesylate } \\
400 \mathrm{mg} \text { tab }\end{array}$ & $0(0.0)$ & NA & $3(75.0)$ & NA & $15(34.1)$ & NA & $18(27.3)$ & NA \\
\hline 41 & Erlotinib & $0(0.0)$ & $0(0.0)$ & $2(50.0)$ & $0(0.0)$ & $5(11.4)$ & $0(0.0)$ & $7(10.6)$ & 0 \\
\hline 42 & Sunitinib 50 mg cap & $0(0.0)$ & NA & $0(0.0)$ & NA & $3(6.8)$ & NA & $3(4.5)$ & NA \\
\hline 43 & $\begin{array}{l}\text { Sorafenib } 200 \mathrm{mg} \\
\text { tab }\end{array}$ & $0(0.0)$ & NA & $1(25.0)$ & NA & $5(11.4)$ & NA & $6(9.1)$ & NA \\
\hline 44 & $\begin{array}{l}\text { Lapatinib } 250 \mathrm{mg} \\
\text { tab }\end{array}$ & $0(0.0)$ & NA & $2(50.0)$ & NA & $13(29.6)$ & NA & $15(23.0)$ & NA \\
\hline
\end{tabular}


Table 3 Continued

\begin{tabular}{|c|c|c|c|c|c|c|c|c|c|}
\hline \multirow[b]{2}{*}{ Sr. No } & \multirow[b]{2}{*}{ Medicine and dose } & \multicolumn{2}{|c|}{ Public hospitals $(n=18)$} & \multicolumn{2}{|c|}{$\begin{array}{l}\text { Private hospitals } \\
(n=4)\end{array}$} & \multicolumn{2}{|c|}{$\begin{array}{l}\text { Private pharmacies } \\
(n=44)\end{array}$} & \multicolumn{2}{|c|}{ All $(n=66)$} \\
\hline & & OB & LPG & OB & LPG & OB & LPG & OB & LPG \\
\hline 45 & Nilotinib 200 mg cap & $0(0.0)$ & NA & $3(75.0)$ & NA & $19(43.2)$ & NA & 22 (33.3) & NA \\
\hline 46 & $\begin{array}{l}\text { Pazopanib } 400 \mathrm{mg} \\
\text { tab }\end{array}$ & $0(0.0)$ & NA & $1(25.0)$ & NA & $4(9.1)$ & NA & $5(7.6)$ & NA \\
\hline 47 & Ruxolitinib & $0(0.0)$ & $0(0.0)$ & $0(0.0)$ & $0(0.0)$ & $3(6.8)$ & $0(0.0)$ & $3(4.6)$ & $0(0.0)$ \\
\hline Total & percentage & 0.0 & 0.0 & 37.5 & 0.0 & 19.0 & 0.0 & 14.9 & 0.0 \\
\hline \multicolumn{10}{|c|}{ Monoclonal antibodies } \\
\hline 48 & Rituximab & $0(0.0)$ & $0(0.0)$ & $1(25.0)$ & $0(0.0)$ & $5(11.4)$ & $0(0.0)$ & $6(9.1)$ & $0(0.0)$ \\
\hline 49 & Trastuzumab & $0(0.0)$ & $0(0.0)$ & $0(0.0)$ & $0(0.0)$ & $2(4.6)$ & $0(0.0)$ & $2(3.0)$ & $0(0.0)$ \\
\hline 50 & Cetuximab & $0(0.0)$ & $0(0.0)$ & $0(0.0)$ & $0(0.0)$ & $2(4.6)$ & $0(0.0)$ & $2(3.0)$ & $0(0.0)$ \\
\hline Total & | percentage & 0.0 & 0.0 & 8.3 & 0.0 & 6.8 & 0.0 & 5.1 & 0.0 \\
\hline $\begin{array}{l}\text { Total } \\
\text { (biolo }\end{array}$ & $\begin{array}{l}\text { I percentage } \\
\text { ogics) }\end{array}$ & 0.0 & 0.0 & 29.6 & 0.0 & 15.7 & 0.0 & 12.3 & 0.0 \\
\hline $\begin{array}{l}\text { Total } \\
\text { (biolo }\end{array}$ & $\begin{array}{l}\text { I percentage } \\
\text { ogics+non-biologics) }\end{array}$ & 25.1 & 8.8 & 62.5 & 15.6 & 49.8 & 26.4 & 43.9 & 21.3 \\
\hline
\end{tabular}

cap, capsule; inj, injection; LPG, lowest price generic; NA, not available; OB, originator brand; tab, tablet.

the hospitals to purchase costly substitute with the annual expense of US\$200 million-US\$216 million. ${ }^{32}$ However, a restraint healthcare sector such as government hospitals of an economically developing country like Pakistan finds it very difficult to bear such expenses. The responsibility lies on the government to provide adequate funds and pay attention towards the development of new healthcare projects.

\section{Availability of biologics versus non-biologics anticancer medicines}

Unlike the non-biologics such as platinum compounds, alkylating agents, plant alkaloids, antimetabolites and hormone antagonist, biologics were less readily available in both sectors. Moreover, none of the biosimilar or generic version was available for any of the selected biologics (table 4) because of prolonged patent period and data exclusivity. According to the Trade-Related Aspects of Intellectual Property Rights (TRIPS) agreement, Pakistan has a right to include in its patent legislation a provision of manufacturing LPGs without the requisition of any consent from the patent holder since Pakistan is a member of the World Trade Organization. Many developed countries have imposed data exclusivity on low/middle-income countries including Pakistan since regulatory approval depends on the bioequivalence studies which in turn depends on originator's data. ${ }^{33}$ Furthermore, the unavailability of facilities (instruments, methods/techniques, skilled personnel) for the manufacturing process hinders the availability of biosimilar products. Though no country can ensure the availability of all biologic anticancer medicines but certain countries such as Japan and Spain have made nearly half of the biologics available for patients with cancer. ${ }^{34}$ Currently,
India is manufacturing many new entities for cancer treatment, but their import is prohibited in Pakistan because of several political issues. Internationally, the focus is being given on the research of biological medicines for cancer treatment because these agents are more effective compared with the pharmaceutical moieties. However, in Pakistan, the government shows reluctance towards the availability of biosimilar products. It can be possibly attributed to the fact that these agents need expensive testing like clinical trials to ensure their similarity with the biologics. Thus, safety guidelines of the WHO must be implicated on national level for the availability of biosimilar products. Otherwise, non-comparable biological products can be deleterious for the patients. Hence, it is recommended that patent periods must be limited. Also, government should add TRIPS flexibility in its patent legislation. In this way, LPCs can have legal rights to manufacture LPGs.

In LMICs like Pakistan, the retail prices are the major deterrent to access when compared with the cost at the supplier level. ${ }^{35}$ Owing to this reason, the availability of non-biologics $(\mathrm{OBs}=52.8 \%, \mathrm{LPGs}=24.3 \%)$ in the current study was found to be less than $100 \%$. In Pakistan, anticancer medicines do not enjoy tax-free status, so the high taxation associated with these life-saving medicines is a huge burden for the cancer sufferers. All the national and international organisations such as the WHO, HAI, The United States Agency for International Development, United Nations Organization and Drug Regulatory Authority of Pakistan must provide adequate funding so that tax-free anticancer medicines can be made available to the local masses. 
Table 4 Affordability of anticancer medicines by high-income, middle-income and low-income class patients in Punjab, Pakistan

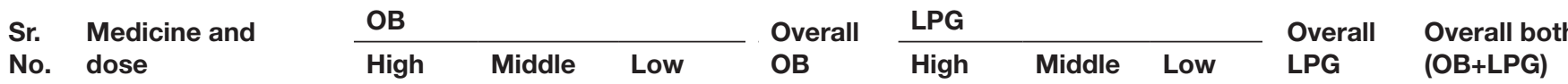

(A) Non-biologics

\section{(i) Alkylating agent}

$\begin{array}{llrrrrrrrrr}1 & \begin{array}{l}\text { Cyclophosphamide } \\ \text { 500 mg inj }\end{array} & 100 & 65.5 & 28.0 & 70.5 & 100 & 95.9 & 57 & 86.6 & 77.0 \\ 2 & \text { Ifosfamide 1 g inj } & 62.9 & 29.5 & 9.1 & 42.3 & 62.9 & 29.2 & 8.8 & 33.5 & 38.8 \\ 3 & \text { Temozolomide } & 2.6 & 1.9 & 0.4 & 1.6 & \text { NA } & \text { NA } & \text { NA } & \text { NA } & 1.6 \\ 4 & \text { Dacarbazine 200 mg } & 100 & 77.8 & 53.6 & 78.3 & 100 & 100 & 67.9 & 90 & 83.4\end{array}$

$4 \quad$ Daca

$\begin{array}{lllllllll}\text { Total } & 66.4 & 43.7 & 22.8 & 48.2 & 87.6 & 75.0 & 44.7 & 70.0\end{array}$

(ii) Hormone antagonist

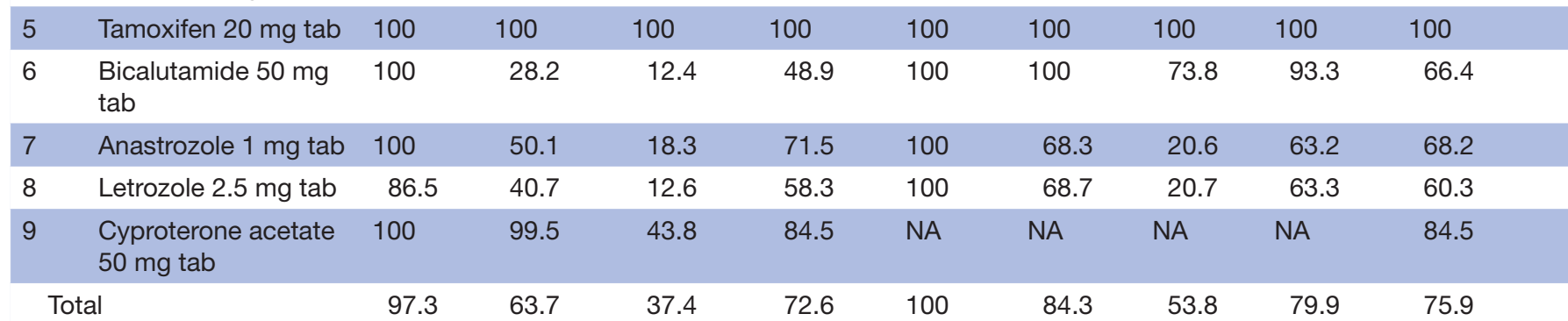

(iii) Antimetabolite

\begin{tabular}{|c|c|c|c|c|c|c|c|c|c|c|}
\hline 10 & Pemetrexed & 2.9 & 1.8 & 0.6 & 1.8 & NA & NA & NA & NA & 1.8 \\
\hline 11 & $\begin{array}{l}\text { Mercaptopurine } 50 \\
\text { mg tab }\end{array}$ & 100 & 100 & 100 & 100 & 100 & 100 & 100 & 100 & 100 \\
\hline 13 & Cytarabine 100 mg inj & 100 & 100 & 69.9 & 92.5 & 100 & 100 & 100 & 100 & 94.7 \\
\hline 14 & $\begin{array}{l}\text { Fluorouracil } 500 \mathrm{mg} \\
\text { inj }\end{array}$ & 100 & 100 & 60.9 & 90.6 & 100 & 100 & 100 & 100 & 94.4 \\
\hline 15 & Gemcitabine $1 \mathrm{~g}$ inj & 21.3 & 9.7 & 3.5 & 13.2 & 32.4 & 13.5 & 5.2 & 18.1 & 15.1 \\
\hline 16 & $\begin{array}{l}\text { Capecitabine } 500 \mathrm{mg} \\
\text { tab }\end{array}$ & 61.9 & 25.0 & 8.1 & 35.5 & NA & NA & NA & NA & 35.5 \\
\hline \multicolumn{2}{|c|}{ Total } & 45.2 & 49.2 & 35.1 & 49.9 & 74.5 & 64.9 & 62.1 & 64.2 & 51.3 \\
\hline
\end{tabular}

(iv) Cytotoxic antibiotics

\begin{tabular}{|c|c|c|c|c|c|c|c|c|c|c|}
\hline 17 & $\begin{array}{l}\text { Dactinomycin } 0.5 \text { mg } \\
\text { inj }\end{array}$ & 100 & 42.6 & 14.7 & 66.1 & 100 & 51.8 & 17.8 & 56.4 & 62.3 \\
\hline 18 & Doxorubicin 50 mg inj & 100 & 62.5 & 27.8 & 68.7 & 100 & 93.5 & 39.5 & 80.3 & 73.0 \\
\hline 20 & Epirubicin 50 mg inj & 75.3 & 28.6 & 9.0 & 44.2 & 96.4 & 38.1 & 19.1 & 55.3 & 48.6 \\
\hline 21 & Idarubicin & 4.8 & 3.2 & 0.3 & 2.8 & NA & NA & NA & NA & 2.8 \\
\hline 23 & Bleomycin 15 mg inj & 68.3 & 18.1 & 6.5 & 27.8 & 78.8 & 46.6 & 15.4 & 46.9 & 36.0 \\
\hline 24 & Mitomycin 10 mg inj & 100 & 100 & 48.5 & 89.2 & 100 & 100 & 100 & 100 & 93.5 \\
\hline \multicolumn{2}{|c|}{ Total } & 81.1 & 50.7 & 21.9 & 55.9 & 95.9 & 71.7 & 39.2 & 70.8 & 59.4 \\
\hline
\end{tabular}

(v) Plant alkaloids

$\begin{array}{llrrrrrrrrr}25 & \text { Vinblastine 10 mg inj } & 100 & 43.2 & 15.6 & 50.5 & 100 & 100 & 43.9 & 81.3 & 63.7 \\ 26 & \text { Vincristine 2 } \mathrm{mg} \text { inj } & 100 & 100 & 85.2 & 96.3 & 100 & 100 & 99.4 & 99.8 & 97.6 \\ 27 & \text { Vinorelbine 50 mg inj } & 100 & 8.7 & 4.8 & 54.6 & 100 & 15.1 & 5.1 & 39.2 & 48.5\end{array}$

Continued 
Table 4 Continued

\begin{tabular}{|c|c|c|c|c|c|c|c|c|c|c|}
\hline \multirow{2}{*}{$\begin{array}{l}\text { Sr. } \\
\text { No. }\end{array}$} & \multirow{2}{*}{$\begin{array}{l}\text { Medicine and } \\
\text { dose }\end{array}$} & \multicolumn{3}{|l|}{ OB } & \multirow{2}{*}{$\begin{array}{l}\text { Overall } \\
\text { OB }\end{array}$} & \multicolumn{3}{|l|}{ LPG } & \multirow{2}{*}{$\begin{array}{l}\text { Overall } \\
\text { LPG }\end{array}$} & \multirow{2}{*}{$\begin{array}{l}\text { Overall both } \\
\text { (OB+LPG) }\end{array}$} \\
\hline & & High & Middle & Low & & High & Middle & Low & & \\
\hline 28 & Etoposide $100 \mathrm{mg}$ inj & 100 & 77.4 & 31.0 & 74.6 & 100 & 92.4 & 43.9 & 82.1 & 77.6 \\
\hline 29 & Paclitaxel 260 mg inf & 23.9 & 8.5 & 4.6 & 15.6 & 23.9 & 14.6 & 5.0 & 14.5 & 15.1 \\
\hline 30 & Docetaxel 80 mg inj & 31.8 & 5.5 & 3.2 & 15.1 & NP & NP & NP & NP & 15.1 \\
\hline 31 & Cabazitaxel & 100 & 36.7 & 28.4 & 55.0 & NA & NA & NA & NA & 55.0 \\
\hline \multicolumn{2}{|c|}{ Total } & 79.4 & 40.0 & 24.7 & 51.7 & 84.8 & 64.4 & 39.5 & 63.4 & 53.2 \\
\hline
\end{tabular}

(vi) Other antineoplastic agents

Platinum compounds

\begin{tabular}{|c|c|c|c|c|c|c|c|c|c|c|}
\hline 32 & Cisplatin 50 mg inj & 100 & 100 & 60 & 91.6 & 100 & 100 & 97.5 & 99.3 & 94.4 \\
\hline 33 & Carboplatin $150 \mathrm{mg}$ inj & 100 & 93.1 & 32.7 & 79.3 & 100 & 100 & 77.1 & 93.6 & 85.0 \\
\hline 34 & Oxalplatin $100 \mathrm{mg}$ inf & 14.5 & 5.8 & 2.0 & 8.2 & 18.0 & 6.6 & 3.5 & 10.3 & 9.1 \\
\hline \multicolumn{2}{|c|}{ Total } & 71.5 & 66.3 & 31.6 & 59.7 & 72.7 & 68.9 & 59.4 & 67.7 & 62.8 \\
\hline \multicolumn{11}{|c|}{ Others } \\
\hline 35 & $\begin{array}{l}\text { Hydroxyurea } 500 \text { mg } \\
\text { cap }\end{array}$ & 100 & 100 & 100 & 100 & NP & NP & NP & NP & 100 \\
\hline
\end{tabular}

\begin{tabular}{|c|c|c|c|c|c|c|c|c|c|c|}
\hline 36 & Topotecan & 3.2 & 2.4 & 1.9 & 2.5 & 20.1 & 18.7 & 6.2 & 15.6 & 9.1 \\
\hline 37 & Irinotecan 100 mg inj & 6.7 & 2.2 & 1.0 & 3.8 & 11.6 & 4.4 & 2.1 & 6.5 & 4.9 \\
\hline \multicolumn{2}{|c|}{ Total } & 36.6 & 34.9 & 34.3 & 35.4 & 15.9 & 11.6 & 4.2 & 11.1 & 38.0 \\
\hline
\end{tabular}

(vii) Other immunosuppressants

\begin{tabular}{|c|c|c|c|c|c|c|c|c|c|c|}
\hline 38 & $\begin{array}{l}\text { Thalidomide } 100 \mathrm{mg} \\
\text { cap }\end{array}$ & 100 & 67.7 & 24.3 & 75.1 & NA & NA & NA & NA & 75.1 \\
\hline 39 & $\begin{array}{l}\text { Methotrexate } 10 \mathrm{mg} \\
\text { tab }\end{array}$ & 100 & 100 & 100 & 100 & 100 & 100 & 100 & 100 & 100 \\
\hline Tota & non-biologics & 74.3 & 51.1 & 31.6 & 56.1 & 82.2 & 67.9 & 47.5 & 66.1 & 58.1 \\
\hline
\end{tabular}

\section{(B) Biologics}

\section{Protein kinase inhibitors}

\begin{tabular}{|c|c|c|c|c|c|c|c|c|c|c|}
\hline 40 & $\begin{array}{l}\text { Imatinib mesylate } 400 \\
\text { mg tab }\end{array}$ & 7.2 & 2.4 & 0.8 & 3.6 & NA & NA & NA & NA & 3.6 \\
\hline 41 & Erlotinib & 2.1 & 1.4 & 0.7 & 1.4 & NA & NA & NA & NA & 1.4 \\
\hline 42 & Sunitinib 50 mg cap & 6.7 & 1.6 & 0.6 & 3.1 & NA & NA & NA & NA & 3.1 \\
\hline 43 & Sorafenib $200 \mathrm{mg}$ tab & 6.3 & 3.2 & 1.1 & 4.3 & NA & NA & NA & NA & 4.3 \\
\hline 44 & Lapatinib 250 mg tab & 8.0 & 3.0 & 1.0 & 5.1 & NA & NA & NA & NA & 5.1 \\
\hline 45 & Nilotinib 200 mg cap & 2.2 & 0.9 & 0.3 & 1.4 & NA & NA & NA & NA & 1.4 \\
\hline 47 & Ruxolitinib & 5.1 & 3.1 & 2.6 & 3.6 & NA & NA & NA & NA & 3.6 \\
\hline \multicolumn{2}{|c|}{ Total } & 6.6 & 2.4 & 1.1 & 3.7 & NA & NA & NA & NA & 3.7 \\
\hline \multicolumn{11}{|c|}{ Monoclonal antibodies } \\
\hline 48 & Rituximab & 3.9 & 2.3 & 1.1 & 2.4 & NA & NA & NA & NA & 2.4 \\
\hline \multicolumn{2}{|c|}{ Total biologics } & 5.8 & 2.3 & 1.1 & 3.3 & NA & NA & NA & NA & 3.3 \\
\hline \multicolumn{2}{|c|}{$\begin{array}{l}\text { Overall total (biologics+non- } \\
\text { biologics) }\end{array}$} & 59.2 & 40.4 & 24.1 & 44.2 & 82.2 & 67.9 & 47.5 & 66.1 & 46.0 \\
\hline
\end{tabular}

cap, capsule; inj, injection; LPG, lowest price generic; NA, not available; NP, not prescribed; OB, originator brand; tab, tablet. 


\section{Affordability of anticancer medicines of OB and LPGs}

The elevated prices of anticancer medicines have made the treatment unaffordable for patients. ${ }^{36}{ }^{37}$ In Pakistan, the proliferation of OBs has economically burdened the local masses, especially the cancer sufferers. ${ }^{38}$ Our findings show that the LPGs $(66.1 \%)$ are more affordable than the OBs $(44.2 \%)$. These lifesaving drugs must be affordable for all income classes but our findings depict the greater affordability (59.2\%) of OBs for high-income patients, less $(40.4 \%)$ for middle-income patients and least $(24.1 \%)$ for low-income patients. In this study, the overall affordability for both OBs and LPGs was found to be $46 \%$ which makes cancer a catastrophic disease, especially for those patients who live below the poverty line in Pakistan. ${ }^{30}$ Unfortunately, the lack of awareness about health insurance has also worsened the situation. Another dilemma of LMICs is that the local masses are unaware of the importance of health insurance. ${ }^{39}$ Insurance policies fail to provide benefits or demand substantial copayment. ${ }^{40}$ Therefore, in 2014 the Pakistani government took an initiative in the form of the Prime Minister National Health Insurance Program. This programme aimed to cover a large number of cancer sufferers in both government and private sectors. However, this programme cannot cover the entire financially constrained civilians of Pakistan without the cooperation of international organisations. The government of Pakistan should follow the footsteps of developed countries where the equality in terms of affordability is being given to every citizen due to their health insurance policies. Health sector and the bank sector must join hands to spread awareness regarding the beneficial attributes of health insurance schemes.

\section{Affordability of biologic versus non-biologic anticancer medicines}

Our findings showed that biologics $(3.3 \%)$ were less affordable than non-biologics $(58.1 \%)$. Affordability of biologics in cancer therapy is particularly a huge problem for both high-income countries and LMICs. In 2011, a drug expenditure analysis demonstrated that biologic anticancer medicines accounted for $55 \%$ of the health expenditure in the USA. ${ }^{41}$ The advent of biologics has improved the survival rate but patients usually show non-compliance and discontinue therapy within 6 months. Previously published literature has declared the high cost as a barrier towards patient's adherence. ${ }^{42}$ This leads to disease progression and treatment resistance.

The findings also demonstrated that non-biologic anticancer medicines $(31.6 \%)$ were more affordable for low-income patients than biologic medicines $(1.1 \%)$. As per an estimation made in $2017,11 \%$ of the Pakistani population are living below the poverty line, and a person can earn an average of PKR12 000-PKR13000 (US\$108.3US\$117.3) per month which amounts to PKR400-433.33 (US\$3.6-US\$3.9) per day. Their low monthly income serves as the root cause of unaffordability of biologic medicines. In Pakistan, lack of public health insurance policies and out-of-pocket monthly premium of private health insurance policies have compelled people to bear health expense on their own. In high-income countries like the USA where people earn US $\$ 3500-U S \$ 4000$ a month, the average daily cost of biologics is 22 times higher than that of non-biologics. ${ }^{43}$ Such high prices cannot be covered by the public health insurance policies, therefore in high-income countries, insurers have to pay $20 \%$ of the drug price. ${ }^{44}$

For biologics, the biosimilars or LPGs are not available, and as a consequence prescribers are compelled to prescribe OBs. According to the Patent Ordinance 2000, the life of a patent is prolonged in Pakistan (ie, 20 years). This has forbidden local manufacturers to make inexpensive versions of the biologics. In Pakistan, there is a dearth of clinical trials. Therefore, biologics have to be imported from developed countries. However, in contrast to European countries, the government is less likely to negotiate on price referencing with the MPCs. ${ }^{45}$ Thus, there is a dire need to strengthen the research and development area of both pharmaceutical and biopharmaceutical industries in Pakistan.

\section{CONCLUSION}

Current study showed that most of the patients with cancer were prescribed non-biologics due to their low price and better affordability. There was fairly high availability of non-biologics compared with biologics. The overall affordability of LPGs was higher compared with OBs for low-income patients irrespective of the fact whether the cancer medicine was biologic or non-biologic. The inequality in terms of affordability is primarily governed by prolonged patent periods of OBs and lack of awareness regarding health insurance schemes. Thus, it is the need of the hour to pay special consideration on ways of improving national health policies or else cancer will continue to ruin patients physically and financially.

Acknowledgements The authors would like to express wholehearted thankfulness to patients and their advisers. The authors wish to express gratitude to Dr Tayyaba Sadiq (Lecturer, Akhtar Saeed College of Pharmaceutical Sciences, Pakistan) for editing the manuscript and giving useful suggestions. Also, a note of thanks to all pharmacy students who acted as data collectors.

Contributors MRS conceptualised and designed the study. AS and SI analysed and interpreted the data. MRS and AS drafted the manuscript. SI and MRS critically revised the manuscript. All authors read and approved the final version of the manuscript.

Funding The authors have not declared a specific grant for this research from any funding agency in the public, commercial or not-for-profit sectors.

Competing interests None declared.

Patient consent Obtained.

Ethics approval The Pharmacy Research Ethics Committee (PREC) at Akhtar Saeed College of Pharmaceutical Sciences (reference: 14-2016/PREC, 25 December 2016).

Provenance and peer review Not commissioned; externally peer reviewed.

Data sharing statement The raw data on which conclusions of this manuscript rely are available upon request. Please contact MRS at rehansarwaralvi@gmail. com. 
Open access This is an open access article distributed in accordance with the Creative Commons Attribution Non Commercial (CC BY-NC 4.0) license, which permits others to distribute, remix, adapt, build upon this work non-commercially, and license their derivative works on different terms, provided the original work is properly cited and the use is non-commercial. See: http://creativecommons.org/ licenses/by-nc/4.0/

(c) Article author(s) (or their employer(s) unless otherwise stated in the text of the article) 2018. All rights reserved. No commercial use is permitted unless otherwise expressly granted.

\section{REFERENCES}

1. Albreht T, McKee M, Alexe DM, et al. Making progress against cancer in Europe in 2008. Eur J Cancer 2008;44:1451-6.

2. FaD A. What Are "Biologics" Questions and Answers, 2018.

3. Oldham RK, Dillman RO. Monoclonal antibodies in cancer therapy: 25 years of progress. J Clin Oncol 2008;26:1774-7.

4. de Souza JA, Wong Y-N. Financial distress in cancer patients. J Med Person 2013;11:73-7.

5. Kantarjian HM, Fojo T, Mathisen M, et al. Cancer drugs in the United States: Justum Pretium--the just price. J Clin Oncol 2013;31:3600-4.

6. Hillner BE, Smith TJ. Efficacy does not necessarily translate to cost effectiveness: a case study in the challenges associated with 21stcentury cancer drug pricing. American Society of Clinical Oncology 2009.

7. Meropol NJ, Schrag D, Smith TJ, et al. American Society of Clinical Oncology. American Society of Clinical Oncology guidance statement: the cost of cancer care. J Clin Oncol 2009;27:3868-74.

8. Mayo Foundation. The high cost of cancer drugs and what we can do about it. Mayo Clinic Proceedings 2012.

9. Cavalli F. Cancer in the developing world: can we avoid the disaster? Nat Clin Pract Oncol 2006;3:582-3.

10. Bigdeli $\mathrm{M}$, Jacobs $\mathrm{B}$, Tomson $\mathrm{G}$, et al. Access to medicines from a health system perspective. Health Policy Plan 2013;28:692-704.

11. Levêque D. Generic drugs in oncology. Lancet Oncol 2017;18:e63.

12. Smith SK, Nicolla J, Zafar SY. Bridging the gap between financial distress and available resources for patients with cancer: a qualitative study. J Oncol Pract 2014;10:e368-e372.

13. Zafar SY, Peppercorn JM, Schrag D, et al. The financial toxicity of cancer treatment: a pilot study assessing out-of-pocket expenses and the insured cancer patient's experience. Oncologist 2013;18:381-90.

14. Vogler S, Zimmermann N, Habl C. Understanding the components of pharmaceutical expenditure-overview of pharmaceutical policies influencing expenditure across European countries. Generics and Biosimilars Initiative Journal 2013;2:178-87.

15. Howard DH, Bach PB, Berndt ER, et al. Pricing in the Market for Anticancer Drugs. J Econ Perspect 2015;29:139-62.

16. Cheema PK, Gavura S, Migus M, et al. International variability in the reimbursement of cancer drugs by publically funded drug programs. Curr Oncol 2012;19:e165-76.

17. Atif M, Ahmad M, Saleem Q, et al. Pharmaceutical Policy in Pakistan. Pharmaceutical Policy in Countries with Developing Healthcare Systems: Springer 2017:25-44.

18. Jamshed $S Q$, Malik MA, Löfgren $\mathrm{H}$, et al. The pharmaceutical industry, intellectual property rights and access to medicines in Pakistan. The New Political Economy of Pharmaceuticals: Springer 2013:167-84.

19. Organization WH. Measuring medicine prices, availability, affordability and price components, 2008.

20. GoPSDPBoS I. Household Integrated Economic Survey (HIES) Pakistan, 2016.
21. Fedral Board of Revenue. Tax Payer Online Verification.

22. Neeshat M. PharmaGuide. Karachi, Pakistan, 2016.

23. Yang $\mathrm{H}$, Dib HH, Zhu M, et al. Prices, availability and affordability of essential medicines in rural areas of Hubei Province, China. Health Policy Plan 2010;25:219-29.

24. Khatib R, McKee M, Shannon $\mathrm{H}$, et al. PURE study investigators. Availability and affordability of cardiovascular disease medicines and their effect on use in high-income, middle-income, and lowincome countries: an analysis of the PURE study data. Lancet 2016;387:61-9.

25. Cameron A, Ewen M, Ross-Degnan D, et al. Medicine prices, availability, and affordability in 36 developing and middle-income countries: a secondary analysis. Lancet 2009;373:240-9.

26. Smith MC. Pharmaceutical marketing: strategy and cases: CRC Press, 1991.

27. Kolasani BP, Malathi DC, Ponnaluri RR. Variation of Cost among Anti-cancer Drugs Available in Indian Market. J Clin Diagn Res 2016;10:FC17.

28. Irfan SM, ljaz A, Shahbaz S. An assessment of service quality of private hospitals in Pakistan: a patient perspective. Indian Journal of Commerce and Management Studies 2011;2:20-32.

29. Brugha R, Zwi A. Improving the quality of private sector delivery of public health services: challenges and strategies. Health Policy Plan 1998;13:107-20.

30. Farmer P, Frenk J, Knaul FM, et al. Expansion of cancer care and control in countries of low and middle income: a call to action. Lancet 2010;376:1186-93.

31. Alwan AD, Maclean D, Mandil A, et al. Assessment of national capacity for noncommunicable disease prevention and control: the report of a global survey, 2001.

32. McBride A, Holle LM, Westendorf C, et al. National survey on the effect of oncology drug shortages on cancer care. Am J Health Syst Pharm 2013;70:609-17.

33. Diependaele L, Cockbain J, Sterckx S. Raising the Barriers to Access to Medicines in the Developing World - The Relentless Push for Data Exclusivity. Dev World Bioeth 2017;17:11-21.

34. Prasad V, De Jesús K, Mailankody S. The high price of anticancer drugs: origins, implications, barriers, solutions. Nat Rev Clin Oncol 2017;14:381-90.

35. Milani B, Scholten W, Organization WH. The world medicines situation 2011. Access to controlled medicines, 2011.

36. Buffery D. The 2015 Oncology Drug Pipeline: Innovation Drives the Race to Cure Cancer. Am Health Drug Benefits 2015;8:216-22.

37. Sullivan R, Peppercorn J, Sikora K, et al. Delivering affordable cancer care in high-income countries. Lancet Oncol 2011;12:933-80.

38. Zaidi S, Bigdeli M, Aleem N, et al. Access to essential medicines in Pakistan: policy and health systems research concerns. PLoS One 2013;8:e63515.

39. Gota VS, Patial P. Toward better quality of anticancer generics in India. Indian J Cancer 2014;51:366-8.

40. van Doorslaer E, O'Donnell O, Rannan-Eliya RP, et al. Catastrophic payments for health care in Asia. Health Econ 2007;16:1159-84.

41. Doloresco F, Fominaya C, Schumock GT, et al. Projecting future drug expenditures: 2011. Am J Health Syst Pharm 2011;68:921-32.

42. Gellad WF. Targeted cancer therapy: from bench to bedside to patient: American Society of Clinical Oncology, 2013.

43. Price W, Nicholson I, Rai AK. Manufacturing barriers to biologics competition and innovation. lowa L. Rev 2015;101:1023.

44. Malik NN. Controlling the cost of innovative cancer therapeutics. Nat Rev Clin Oncol 2009;6:550-2.

45. Cherny N, Sullivan R, Torode J, et al. ESMO European Consortium Study on the availability, out-of-pocket costs and accessibility of antineoplastic medicines in Europe. Ann Oncol 2016;27:1423-43. 